\title{
In reply Demirtaş et al.,
}

\author{
(1) Ayla Demirtaş ${ }^{1}$, (1) Gülten Güvenç${ }^{1}$, (1) Özlem Aslan², (1) Emine Öksüz', (1) Ayşe Kılıç Uçar ${ }^{3}$ \\ 1 University of Health Sciences Turkey, Gülhane School of Nursing, Ankara, Turkey \\ 2Ufuk University, School of Nursing, Ankara, Turkey \\ 3/stanbul Bilim University, Florence Nightingale School of Nursing, Istanbul, Turkey
}

Date submitted:

07.04.2021

Date accepted:

13.04.2021

Online publication date:

15.06.2021

\section{Corresponding Author:}

Ayla Demirtaş, PhD, RN, Assistant Professor, University of Health

Sciences Turkey, Gülhane Faculty of Nursing, Ankara, Turkey

\section{ORCID:}

orcid.org/0000-0001-7952-770X

\section{Dear Editor,}

We are pleased to respond to the valuable comments (1) regarding our article titled "Determination of the Anxiety and the Needs of Family Members of Critical Care Patients in Emergency Departments" (2).

The study was planned when many new violence cases against healthcare staff in the emergency facilities appeared on media sources a couple of years ago, which drove our focus on patient relatives. Our results have shown that effective communication and cooperation between healthcare staff and relatives of the patients can prevent conflict and chaos in emergency services. Unfortunately, the risk of such unwanted events increases in the emergency services.

As emphasized by the authors of the correspondence, empathy with the patient and accompanying people, understanding their needs can yield good communication, which in turn increases the quality of care received by the patient and the carer. As such, the relatives or the carers may feel more confident with the healthcare service, and negative thoughts and behaviors can be prevented (3-5).

Notwithstanding, our results cannot be generalized to other settings like primary care services, home care or outpatient clinics of tertiary care facilities.

\section{Ethics}

Peer-review: Internally peer-reviewed.

Financial Disclosure: The authors declared that this study received no financial support.

\section{References}

1. Karasahin KE. Understanding the anxiety and the needs of families helps to prevent crisis and medicolegal complaints. Gulhane Med J 2021;63:163-164.

2. Demirtas A, Guvenc G, Aslan O, Oksuz E, Ucar AK. Determination of the anxiety and the needs of family members of critical care patients in emergency departments. Gulhane Med J. 2020;62:231-238.

3. Solmaz B, Duğan Ü. Sağlık çalışanı ile hasta ve yakınları arasında yaşanan şiddetin nedenlerinden “iletişim” üzerine bir inceleme. AlBÜ Sosyal Bilimler Enstitüsü Dergisi. 2018;2:185-206.

4. Leventhal EL, Schreyer KE. Information management in the emergency department. Emerg Med Clin North Am. 2020;3:681-691.

5. Hsiao PR, Redley B, Hsiao YC, et al. Family needs of critically ill patients in the emergency department. Int Emerg Nurs. 2017;30:3-8. 